\title{
CITA HUKUM POSITIF INDONESIA DAN ASEAN ECONOMIC COMMUNITY (AEC)
}

\section{Ahmad Hunaeni Zulkarnaen \\ Dosen Fakultas Hukum, dan dosen Masgister Pascasarjana Ilmu Hukum Universitas Suryakancana}

\begin{abstract}
ABSTRAK
Masyarakat Ekonomi ASEAN, adalah sebuah masyarakat yang saling terintegrasi satu sama lain dalam lingkup ASEAN dimana adanya perdagangan bebas diantara negara-negara anggota ASEAN dengan tujuan untuk mengubah ASEAN menjadi kawasan yang lebih stabil, makmur dan kompetitif dalam pembangunan ekonomi, dengan karakteristik: (a) berbasis pada pasar tunggal dan produksi, (b) kawasan ekonomi yang sangat kompetitif, (c) wilayah pembangunan ekonomi yang adil, dan (d) kawasan yang begitu terintegrasi dalam hal ekonomi global. Semua sistem hukum Indonesia yang dibuat dan diberlakukan dalam rangka pelaksanaan "ASEAN Economic Community (AEC) harus sebagai jembatan dan pintu gerbang untuk mencapai masyarakat Indonesia yang adil dan makmur berdasarkan Pancasila.
\end{abstract}

Kata kunci : ASEAN Economic Community (AEC), keadilan, kemakmuran.

\section{ABSTRACT}

ASEAN Economic Community, is a society that is integrated each other within the scope of ASEAN where free trade among the ASEAN members by the aim to create ASEAN become more stable, prosperous and competitive in development economically, with the following characteristics: (a) based on a single market and production, (b) highly competitive in regions economy, (c) equitable development in regions economy, and $(d)$ integrated regions in the global economy.

All of the Indonesian legal systems are created and applied for the implementation of the "ASEAN Economic Community (AEC) must be an intermediary and a gateway in achieving fairness and prosperity for Indonesian citizens based on Pancasila .

Keywords : ASEAN Economic Community (AEC), fairness, prosperity.

\section{PENDAHULUAN.}

Hukum bukan tujuan melainkan pencerminan aspirasi masyarakat dan sebagai pintu gerbang menuju kepada ide yang dicita-citakan. ${ }^{1}$ sistem hukum

1 Sunaryati Hartono, Politik Hukum Menuju Sistem Hukum Nasional, PT. Alumni, Bandung, 1991, hlm. 1. 
harus sesuai dengan ide yang di cita-citakan. ${ }^{2}$ hukum merupakan alat tujuan negara. ${ }^{3}$

Supomo berpendapat, tujuan hukum mengatur pergaulan hidup secara damai, dan melindungi kepentingan-kepentingan manusia (kehormatan, kemerdekaan, jiwa, harta, hak dan lain-lain), terhadap yang merugikannya. ${ }^{4}$

Cita hukum, adalah gagasan, karsa, cipta dan pikiran berkenaan dengan persepsi makna hukum, makna hukum berintikan kehasilgunaan, kepastian, prediktabilitas, dan keadilan ${ }^{5}$. Cita hukum Indonesia adalah kehidupan kebangsaan yang adil dan makmur berdasarkan Pancasila sebagaimana tertuang dalam alinea ke 4 (empat) pembukaan Undang-Undang Dasar Tahun 1945, artinya semua sistem hukum yang dibuat dan diberlakukan harus sebagai jembatan dan pintu gerbang untuk mencapai masyarakat Indonesia yang adil dan makmur berdasarkan Pancasila. ${ }^{6}$

Berdasarkan cita hukum Indonesia keberadaan "ASEAN Economic Community (AEC) harus dapat mengatur pergaulan hidup secara damai, dan melindungi kepentingan-kepentingan diantara sesama anggota ASEAN (kehormatan, kemerdekaan, jiwa, harta, hak dan lain-lain), terhadap yang merugikannya, keberadaan "ASEAN Economic Community (AEC) harus dapat mewujudkan cita hukum Indonesia yaitu kehidupan kebangsaan yang adil dan makmur berdasarkan Pancasila sebagaimana tertuang dalam alinea ke 4 (empat) pembukaan Undang-Undang Dasar Tahun 1945.

Semua sistem hukum yang dibuat dan diberlakukan dalam rangka pelaksanaan "ASEAN Economic Community (AEC) harus sebagai jembatan dan pintu gerbang untuk mencapai masyarakat Indonesia yang adil dan makmur berdasarkan Pancasila.

\footnotetext{
Ibid.

Moh. Mahfud MD, Politik Hukum di Indonesia, PT Raja Grafindo Persada, Jakarta, Tahun 2009, hlm. 2.

4 L.J. van Apeldoorn, Pengantar Ilmu Hukum, PT. Pradnya Paramita, Cetakan ke 21 (dua puluh satu), Jakarta, 1983, hlm. 22.

5 Arief Sidharta, Cita Hukum Pancasila, Makalah Kuliah Program Pasca Sarjana DIH, tanpa penerbit, tempat, tahun dan tanpa hlm. Ibid.
}

6

Vol. II No. 01 Edisi Januari-Juni 2016. 


\section{PEMBAHASAN.}

\section{A. Pengertian Masyarakat Ekonomi ASEAN Atau ASEAN Economic Community (AEC).}

\section{Pengertian Secara Umum.}

Secara umum, Masyarakat Ekonomi ASEAN diartikan sebagai sebuah masyarakat yang saling terintegrasi satu sama lain (maksudnya antara negara yang satu dengan negara yang lain dalam lingkup ASEAN) dimana adanya perdagangan bebas diantara negara-negara anggota ASEAN yang telah disepaki bersama antara pemimpin-pemimpin negara-negara ASEAN untuk mengubah ASEAN menjadi kawasan yang lebih stabil, makmur dan kompetitif dalam pembangunan ekonomi. ${ }^{7}$

\section{Pengertian Menurut Organisasi Internasional ASEAN.}

Halaman resmi organisasi internasional ASEAN menyatakan bahwa Masyarakat Ekonomi ASEAN (MEA) merupakan tujuan dari integrasi ekonomi regional kawasan Asia Tenggara yang diberlakukan pada tahun 2015. Karakteristik MEA sendiri meliputi: (1) berbasisi pada pasar tunggal dan produksi, (2) kawasan ekonomi yang sangat kompetitif, (3) wilayah pembangunan ekonomi yang adil, dan (4) kawasan yang begitu terintegrasi dalam hal ekonomi global. ${ }^{8}$

Berdasar telah dipaparkan diatas, pengertian Masyarakat Ekonomi ASEAN, adalah sebuah masyarakat yang saling terintegrasi satu sama lain dalam lingkup ASEAN dimana adanya perdagangan bebas diantara negara-negara anggota ASEAN dengan tujuan untuk mengubah ASEAN menjadi kawasan yang lebih stabil, makmur dan kompetitif dalam pembangunan ekonomi, dengan karakteristik: (a) berbasis pada pasar tunggal dan produksi, (b) kawasan ekonomi yang sangat kompetitif, (c) wilayah pembangunan ekonomi yang adil, dan (d) kawasan yang begitu terintegrasi dalam hal ekonomi global.

7 Bambang Rahardjo, Sumber :http://sukasosial.blogspot.com/2015/08/ masyarakat-ekonomiasean.html Ibid.

Vol. II No. 01 Edisi Januari-Juni 2016. 


\section{B. Cita Hukum Positif Indonesia dan ASEAN Economic Community (AEC).}

Seluruh sistem hukum positif (termasuk sistem hukum positif "ASEAN Economic Community/MEA: penulis) harus dipersepsi oleh cita hukum Indonesia yang tertuang dalam pembukaan Undang-Undang Dasar 1945. Seluruh sistem hukum positif harus sebagai instrument dalam rangka mencapai tujuan pembangunan nasional Indonesia yaitu mewujudkan masyarakat adil dan makmur, merata materiil dan spiritual dalam era demokrasi ekonomi Pancasila dan Undang-Undang Dasar 1945. ${ }^{10}$

Berdasarkan paparan di atas, seluruh sistem hukum positif ASEAN Economic Community (AEC) harus sebagai instrument dalam rangka mencapai tujuan pembangunan negara-negara ASEAN, yaitu mewujudkan masyarakat adil dan makmur, merata materiil dan spiritual dalam era demokrasi ekonomi Pancasila dan Undang-Undang Dasar 1945.

Ke 5 (lima) sila Pancasila merupakan suatu kesatuan yang bulat dan utuh, masing-masing sila tidak dapat dipahami dan diberi arti secara sendiri-sendiri terpisah dari keseluruhan sila lainnya.

Berdasarkan pendapat dari L.J. Van Apeldoorn untuk negara Indonesia dalam kehidupan ASEAN Economic Community (AEC) tidak boleh terdapat perbedaan-perbedaan menyolok, dalam menyelesaikan setiap permasalahan tidak dilakukan dengan cara yang ekstrim tetapi dengan cara musyawarah berdasarkan falsafah persatuan bukan berdasarkan falsafah lain (kapitalisme, komunisme, religius), dan merukunkan (menyeimbangkan) secara adil kepentingankepentingan diantara sesama anggota ASEAN Economic Community.

Negara-negara ASEAN harus melindungi yang meliputi segenap bangsanya secara seluruhnya, ASEAN Economic Community (AEC) harus mengedepankan paham persatuan dan paham persatuan harus mengatasi pahampaham atau ideology-idiologi yang berlaku dimasing-masing negara yang

10 Sentosa Sembiring, Himpunan Undang-Undang Tentang Perlindungan Konsumen dan Peraturan Perundang-Undangan Yang Terkait, Nuansa Aulia, Bandung, 2007, hlm. 9.

Vol. II No. 01 Edisi Januari-Juni 2016. 
tergabung dalam ASEAN Economic Community (AEC), misalnya mengatasi paham individualisme, mengengedepankan paham persatuan yang meliputi segenap bangsa-bangsa ASEAN secara keseluruhan.

\section{Sistem Demokrasi Ekonomi Indonesia dan ASEAN Economic Community (AEC).}

Sistem pembangunan ASEAN Economic Community (AEC) harus sejalan dengan sistem pembangunan ekonomi Indonesia. Pembangunan ekonomi Indonesia menganut sistem demokrasi ekonomi dengan paham negara hukum modern, negara mengutamakan kepentingan umum dan aktif mengatur pergaulan hidup masyarakat, termasuk dalam bidang lapangan kerja. ${ }^{14}$

Indonesia selain sebagai negara hukum juga sebagai negara demokratis, demokratis adalah berkaitan dengan sistem pemerintahan suatu negara, yaitu pemerintahan dari rakyat, oleh rakyat dan untuk rakyat, ${ }^{15}$ konsep dasar demokrasi, adalah kekuasaan ditangan rakyat, daulat rakyat. ${ }^{16}$

Indonesia menganut paham demokrasi konstitusional, dimana kekuasaan pemerintah dibatasi oleh peraturan perundang-undangan, pemerintah tidak dibenarkan bertindak sewenang-wenang atau menyalahgunakan kewenangannya sehingga merugikan warga negaranya, perumusan yuridis dari prinsip-prinsip ini terkenal dengan Rechtsstaat dan Rule of Law. ${ }^{21}$

Paham demokrasi tidak bisa dilepaskan dari paham negara hukum, sebab pada akhirnya hukum yang mengatur dan membatasi kekuasaan negara atau pemerintah, diartikan sebagai hukum yang dibuat atas dasar kekuasaan atau kedaulatan rakyat, sehingga sering disebut sebagai negara hukum yang demokratis (democratisch rechtsstaat), ${ }^{25}$ kedaulatan rakyat (democratie beginsel)

\footnotetext{
Ibid.hlm 10.

Bondan Gunawan, Apa Itu Demokrasi, Pustaka Sinar Harapan, Jakarta, 2000, hlm. 1. Ibid.

Mariam Budiarjo, Dasar-Dasar IImu Politik, Gramedia Pustaka Utama, Cetakan XIII, Jakarta, 1991, hlm .52.

25 Bagir Manan, Hubungan Antara Pusat dan Daerah Menurut UUD 1945, Sinar Harapan, Jakarta, 1994, hlm. 167.
} 
sebagai salah satu asas dari negara hukum, ${ }^{26}$ disamping kesejahteraan rakyat, kedaulatan rakyat merupakan unsur material negara hukum. ${ }^{27}$

Salah satu asas penting negara hukum adalah asas legalitas, asas legalitas ini berkaitan erat dengan dengan gagasan demokrasi dan gagasan negara hukum (het democratish ideal en het rechtsstaats ideal), asas ini menuntut setiap bentuk undang-undang dan berbagai keputusan harus mendapat persetujuan dari wakil rakyat dan sebanyak mungkin memperhatikan kepentingan rakyat, atau gagasan negara hukum menuntut agar penyelenggaraan kenegaraan dan pemerintah harus didasarkan pada undang-undang dan memberikan jaminan kepada hak-hak dasar rakyat yang tertuang dalam undang-undang. ${ }^{28}$

Indonesia menganut sistem demokrasi ekonomi yang konstitusional dengan konsep negara hukum modern dengan pola negara kesejahteraan, hal ini diketahui dari alinea 4 (empat) pembukaan Undang-Undang Dasar 1945, yang menyebutkan tujuan negara adalah memajukan kesejahteraan umum, Pasal 1 ayat (1) Undang-Undang Dasar 1945 yang menyebutkan; Indonesia adalah negara kesatuan yang berbentuk Republik, kemudian dalam ayat (2) nya menyebutkan ; kedaulatan ada ditangan rakyat, demikian pula dengan Pasal 27 ayat (2) UndangUndang Dasar 1945, yang menyebutkan tugas negara adalah menciptakan lapangan kerja (memberantas pengangguran) dan memberikan penghidupan yang layak bagi kemanusiaan (memberantas kemiskinan), dan Pasal 28 D ayat (2) amandement ke 3 (tiga) Undang-Undang Dasar 1945, yang menyebutkan setiap orang berhak untuk bekerja mendapat imbalan dan perlakuan yang adil dan layak dalam hubungan kerja.

Sistem demokrasi ekonomi Pancasila adalah sistem demokrasi ekonomi konstitusional, konsep negara hukum modern dengan pola negara kesejahteraan, yaitu suatu konsep sistem demokrasi ekonomi yang bukan saja hanya mengejar pertumbuhan untuk sekelompok kecil anggota masyarakat, tetapi juga mengutamakan kesejahteraan bagi seluruh rakyat Indonesia (pemerataan), sistem

\footnotetext{
6 Ibid, hlm. 19.

7 Ibid, hlm. 48.

28 Ni'matul Huda, Op. Cit. hlm. 20.
}

Vol. II No. 01 Edisi Januari-Juni 2016. 
Masyarakat Ekonomi ASEAN (MEA) harus merupakan sub sistem dari sistem integralistik (persatuan) demokrasi ekonomi Pancasila.

\section{ASEAN Economic Community (AEC) dan Konsep Pembangunan}

\section{Indonesia.}

Menurut teori pembangunan yang dikemukakan Rochmat Soemitro:

"Pelaksanaan pembangunan disamping untuk meningkatkan pemerataan pendapatan nasional, sekaligus harus menjamin pembagian pendapatan yang merata bagi seluruh rakyat berasaskan keadilan, tujuan pembangunan selain untuk meningkatkan produksi, juga untuk mempersempit jurang pemisah antara yang kaya dan yang miskin dengan menumbuhkan asas hidup sederhana dan wajar". 31

Mengacu kepada teori pembangunan yang dikemukakan Rochmat Soemitro, keberadaan Masyarakat Ekonomi ASEAN (MEA) disamping untuk meningkatkan pemerataan pendapatan nasional antar negara-negara ASEAN, sekaligus harus menjamin pembagian pendapatan yang merata bagi seluruh rakyat negara-negara ASEAN berasaskan keadilan. Masyarakat Ekonomi ASEAN (MEA) harus mampu meningkatkan produksi di negara-negara ASEAN sehingga mempersempit jurang pemisah antara negara-negara ASEAN yang kaya dan negara-negara ASEAN yang miskin. Pembangunan ekonomi dalam rangka Masyarakat Ekonomi ASEAN (MEA) merupakan Proses multi dimensional yang melibatkan perubahan-perubahan besar dalam struktur sosial, sikap-sikap mental yang sudah terbiasa, dan lembaga nasional termasuk pula percepatan/akselerasi pertumbuhan ekonomi, pengurangan pemberantasan kemiskinan yang absolut pada Masyarakat Ekonomi ASEAN (MEA), khususnya Indonesia. Arah kebijakan pembangunan dalam Masyarakat Ekonomi ASEAN (MEA) harus sejalan dengan tujuan akhir dari arah pembangunan ekonomi nasional Indonesia, yaitu pertumbuhan (produktivitas) dan pemerataan.

Menurut Suprihanto, produktivitas adalah kemampuan seperangkat sumber-sumber ekonomi untuk menghasilkan barang dan jasa. ${ }^{33}$ atau

31 Rochmat Sumitro, Pajak dan Pembangunan, PT. Alumni, Bandung, 1987, hlm. 32

33 Sri Haryani, Hubungan Industrial Di Indonesia, UPP AMP YKPN, Yogyakarta, 2002. hlm. 97.

Vol. II No. 01 Edisi Januari-Juni 2016. 
produktivitas adalah output dibagi input. ${ }^{34}$ Pertumbuhan (produktivitas) nasional berkorelasi dengan peningkatan kesejahteraan rakyat di negara-negara ASEAN. kebutuhan atas penghargaan, dan kebutuhan aktualisasi. ${ }^{35}$ dan prioritas kebutuhan rakyat di Indonesia, baru pada tingkat kebutuhan fisiologis dan keselamatan/keamanan, yaitu cukup untuk memenuhi kebutuhan sandang, papan, pangan, maka dengan adanya Masyarakat Ekonomi ASEAN (MEA) diharapkan Indonesia tidak saja mampu memenuhi kebutuhan sandang, papan, pangan tetapi juga mampu memenuhi kebutuhan akan rasa memiliki, kebutuhan atas penghargaan, dan kebutuhan aktualisasi dalam pergaulannya di Masyarakat Ekonomi ASEAN (MEA).

Menurut Sorjono Soekanto ada 5 (lima) aspek yang menjadi faktor penghambat upaya pemenuhan prioritas kebutuhan rakyat indonesia tersebut, yaitu aspek penegak hukum, aspek sarana atau fasilitas, aspek masyarakat (para pihak), aspek budaya dan aspek hukum (perundang-undangan). ${ }^{36}$ Kelima aspek tersebut saling berkaitan dengan erat, oleh karena merupakan esensi dari penegakan hukum ${ }^{37}$.

Peran hukum dalam hal ini undang-undang (leges, wetten) dalam pembangunan (MEA: Penulis), selain sebagai instrument menyalurkan masyarakat kearah tujuan pembangunan juga menjamin bahwa perubahan akibat pembangunan akan terlaksana secara adil, tertib, dan teratur, oleh karenanya hukum (sistem hukum MEA: penulis) harus dipersepsi dan/atau sebagai bagian dari keseluruhan dan dari kaidah-kaidah, lembaga-lembaga sosial masyarakat. ${ }^{38}$

Menurut Mochtar Kususmaatmadja dan B Arief Sidharta, undangundang (undang-undang Masyarakat Ekonomi ASEAN : Penulis) yang sesuai dengan rasa keadilan masyarakat, adalah undang-undang yang memenuhi moral positif dan/atau kepatutan masyarakat, suatu undang-undang yang mampu

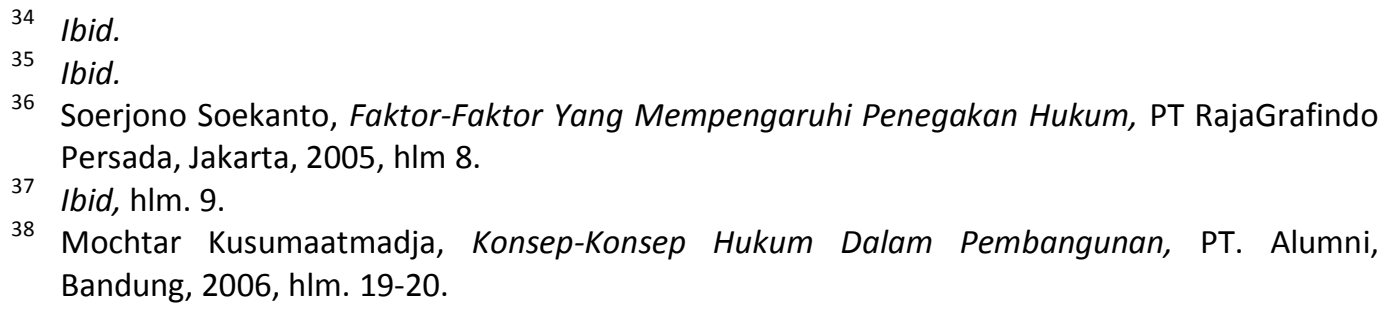


membedakan antara baik dan buruk yang sifatnya heteronom (sudah menjadi keyakinan umum) dan mengingat manusia sebagai makhluk sosial berakal budi dan berhati nurani. ${ }^{39}$

John Stuart Mill, berpendapat sumber dari kesadaran keadilan itu bukan terletak pada kegunaan, melainkan pada rangsangan untuk mempertahankan diri dan perasaan simpatik yaitu bersumber pada nurani manusia yang mencakup semua persyaratan moral yang sangat hakiki begi kesejahteraan umat manusia dan menolak kerusakan. ${ }^{40}$

Keadilan yang merupakan unsur bathiniah dari undang-undang, isi dan ukurannya berbeda-beda, dan konfigurasinya ditentukan oleh tempat dan kapan undang-undang tersebut berlaku, ${ }^{41}$ demikian keadilan yang merupakan unsur bathiniah dari peraturan perundang-undangan Masyarakat Ekonomi ASEAN isi dan ukurannya berbeda-beda, dan konfigurasinya ditentukan oleh tempat (Negara) peraturan perundang-undangan berlaku.

Nilai keadilan harus sesuai dengan kesadaran hukum Masyarakat Ekonomi ASEAN, dan kesadaran hokum Masyarakat Ekonomi ASEAN dipengaruhi oleh paham filosofis, moralitas, keyakinan beragama, kesopanan dan adat istiadat dari Masyarakat Ekonomi ASEAN dimana peraturan perundangundangan tersebut berada atau berlaku.

Jeremy Bentham berpendapat bahwa pembentukan undang-undang hendaknya dapat melahirkan undang-undang yang mencerminkan keadilan bagi semua individu dan dapat memberikan kebahagian yang terbesar bagi sebagian besar masyarakat (the greates happiness for the greatest number). ${ }^{42}$

Sejalan dengan pendapat Jeremy Bentham pembentukan undang-undang Masyarakat Ekonomi ASEAN hendaknya dapat melahirkan undang-undang yang

39 Mochtar Kusumaatmadja, B. Arief Sidharta, Pengantar Ilmu Hukum, PT. Alumni, Bandung, 2000, hlm, 27.

40 Satjipto Rahardjo, Ilmu Hukum, Bandung, PT. Alumni, Bandung, 1982, hlm. 241.

41 Mochtar Kusumaatmadja, Hukum Masyarakat dan Pembinaan Hukum Nasional, PT. Alumni, Bandung, 1976, hlm. 3.

42 Lili Rasjidi, Ira Thania Rasjidi, Pengantar Filsafat Hukum, Mandar Maju, Bandung, 2007, hlm. 61. 
mencerminkan keadilan dan dapat memberikan kebahagian yang terbesar bagi sebagian besar masyarakat yang ada di negara-negara ASEAN.

Cita hukum Indonesia berdasarkan paham demokrasi ekonomi dan negara hukum Pancasila. ${ }^{44}$ berkorelasi dengan teori keadilan etis, protektif (pasif dan aktif), distributif dan komutatif, dan teori keadilan utilitas. Teori keadilan etis dari Aristoteles yang mengajarkan untuk memberikan kepada setiap orang apa yang menjadi bagian atau haknya (ius suum cuique tribuere). ${ }^{45}$ kemudian teori keadilan etis terbagi kedalam teori keadilan distributif dan komutatif.

Teori keadilan distributif mengajarkan memberikan kepada setiap orang bagian sesuai dengan jasanya (asas kesebandingan), dan teori keadilan komutatif mengajarkan untuk memberikan kepada tiap orang bagian yang sama banyak tanpa memperhatikan jasanya (asas persamaan). ${ }^{46}$

Tujuan hukum menurut teori protektif, adalah melindungi manusia dalam arti pasif dan aktif, dalam arti pasif adalah mencegah tidakan sewenang-wenang dan pelanggaran hak, dalam arti aktif adalah menciptakan kondisi kemasyarakatan yang membuka jalan seluas mungkin serta mendorong manusia untuk memanusiakan dirinya atau secara adil, setiap manusia memperoleh kesempatan yang luas untuk mengembangkan seluruh potensi (bakat, kemampuan) kemanusiaannya secara utuh. ${ }^{48}$

Termasuk dalam pengertian rumusan teori protektif adalah tujuan untuk memelihara dan mengembangkan budi pekerti kemanusia serta cita-cita moral rakyat yang luhur berdasarkan Ketuhanan Yang Maha Esa (penjelasan UndangUndang Dasar 1945) yang mencakup usaha untuk mewujudkan, ketertiban, keteraturan, kedamaian sejati (kedamaian yang berketentraman), keadilan (distributif, komutatif, vindikatif, protektif), kesejahteraan dan keadilan sosial,

\footnotetext{
4 Mochtar Kusumaatmadja dan B Arief Sidharta, Op.Cit. hlm. 134-139.

45 Tim Pengajar PIH FH Unpar, Pengangtar Ilmu Hukum, Universitas Katolik Parahyangan, Bandung, 1995. hlm. 36.

46 Ibid.

48 Ibid.
} 
pemeliharaan dan pengembangan akhlak (budi pekerti dan cita-cita moral yang luhur) berdasarkan Ketuhanan Yang Maha Esa. ${ }^{49}$

Salah satu ciri masyarakat adil dan makmur berdasarkan Pancasila dan Undang-Undang Dasar 1945 dalam hubungannya dengan Masyarakat Ekonomi ASEAN, adalah pelaksanaan hak tidak tergantung kepada kekuatan belaka (ekonomi, politik), dan sepanjang tidak melanggar hak dan merugikan orang lain, tanpa rasa khawatir semua pihak (dalam Masyarakat Ekonomi ASEAN) secara bebas dapat menjalankan apa yang diyakininya sebagai benar, mengembangkan bakat, kesenangan-kesenangannya, merasa selalu akan mendapat perlakuan yang wajar, berkemanusiaan, adil dan beradab, ${ }^{50}$ tugas Masyarakat Ekonomi ASEAN, adalah menjamin kesejahteraan masyarakat di negara-negara ASEAN dan memperlakukan masyarakat di negara-negara ASEAN secara manusiawi, wajar, adil dan beradab, hal ini sejalan dengan pendapat SF Marbun; tugas negara hukum pada abad modern ini, menyelenggarakan kepentingan umum dan kesejahteraan rakyat secara langsung. ${ }^{51}$

Sistem hukum Masyarakat Ekonomi ASEAN adalah merupakan instrument untuk mengarahkan semua anggota Masyarakat Ekonomi ASEAN kearah prilaku yang berkeadilan, keadilan adalah: "Iustitia est contains et perpertua voluntas ius suum cuique tribuere", artinya: keadilan adalah secara sukarela tetap dan terus menerus memberikan kepada setiap orang apa yang sudah menjadi bagiannya atau haknya. ${ }^{52}$ perlakuan secara adil merupakan hak semua pihak (Masyarakat Ekonomi ASEAN: penulis), artinya menjamin tidak ada perlakuan yang sifatnya sewenang-wenang (keadilan protektif: penulis). ${ }^{53}$ terhadap sesama anggota Masyarakat Ekonomi ASEAN.

Fungsi hukum yang akan mengatur Mayarakat Ekonomi ASEAN adalah sebagai sarana pembaharuan masyarakat ASEAN, mengarah kepada kondisi masyarakat ASEAN yang lebih baik, hal ini sejalan dengan pemikiran Roscoe

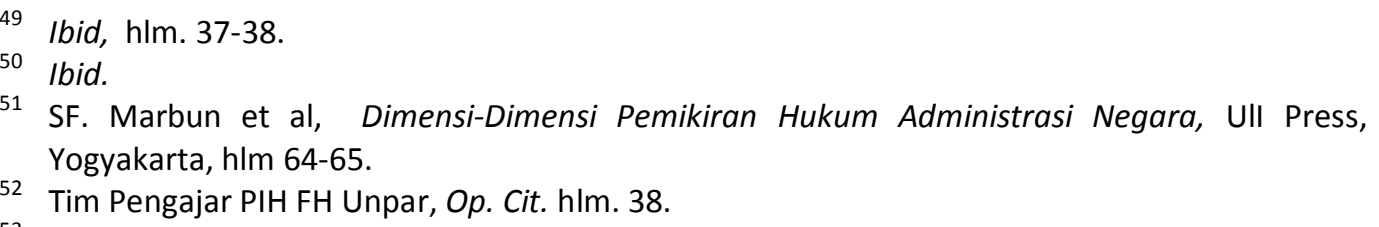


Pound, yaitu fungsi hukum sebagai alat untuk merekayasa masyarakat (law as a tool of social engineering) atau tidak hanya melestarikan status quo, dan menghilangkan kebiasaan masyarakat yang dipandang negative, ${ }^{54}$ demikian juga fungsi hukum yang mengatur Masyarakat Ekonomi ASEAN adalah sebagai alat untuk merekayasa Masyarakat Ekonomi ASEAN atau tidak hanya melestarikan status quo, dan menghilangkan kebiasaan masyarakat negara-negara ASEAN yang dipandang negatif.

Sejalan dengan pendapat Pound diatas, maka perlu dilakukan langkahlangkah penyelesaian masalah (Mayarakat Ekonomi ASEAN : Penulis) yang bersifat sistimatis, dimulai dari indentifikasi problem (Mayarakat Ekonomi ASEAN: Penulis) sampai jalan pemecahannya, yaitu mengenal problem (Mayarakat Ekonomi ASEAN: Penulis) dengan sebaik-baiknya, mahami dan memilih nilai-nilai yang ada (Mayarakat Ekonomi ASEAN: Penulis), membuat dan memilih hipotesis-hipotesis dan mengikuti jalannya penerapan hukum dan mengukur efek-efeknya. ${ }^{55}$

Korelasi konsep Mochtar Kusumaatmadja dengan fungsi hukum Mayarakat Ekonomi ASEAN, adalah hukum Mayarakat Ekonomi ASEAN tidak diartikan sebagai "alat" tetapi sebagai "sarana" pembaharuan Mayarakat Ekonomi ASEAN, dikaitkan dengan pendapat Darji Darmodiharjo dan

Sidharta, bahwa pokok-pokok pikiran yang melandasi konsep tersebut adalah:

1. Ketertiban, keteraturan dalam usaha pembangunan dan pembaharuan sistem hukum (Mayarakat Ekonomi ASEAN: Penulis) memang diinginkan, bahkan mutlak perlu.

2. Hukum (Mayarakat Ekonomi ASEAN: Penulis) diharapkan dapat mengarahkan kegiatan manusia kearah dikehendaki oleh pembangunan (tujuan akhir Mayarakat Ekonomi ASEAN: Penulis). ${ }^{56}$

Diperlukan peraturan hukum tertulis untuk menempatkan hukum (Mayarakat Ekonomi ASEAN: Penulis) agar sesuai dengan harapan tersebut

54 Darji Darmodiharjo, Sidharta, Pokok-Pokok Filsafat Hukum (Apa dan Bagaimana Filsafat Hukum Indonesia), PT Gramedia Pustaka Utama, Jakarta, Tahun 2008, hlm. 197.

55 Satjipto Rahardjo, Op.Cit. hlm. 170-171.

56 Darji Darmodiharjo, Sidharta, Op. Cit. 198.

Vol. II No. 01 Edisi Januari-Juni 2016. 
diatas (baik perundang-undangan maupun yurisprudensi) dan hukum yang tertulis tersebut harus sesuai dengan hukum yang hidup dalam masyarakat. ${ }^{57}$

Pembangunan sistem Masyarakat Ekonomi ASEAN harus merupakan salah satu pilar dari pembangunan ekonomi nasional Indonesia, dan harus merupakan implementasi dari tujuan Negara Indonesia sebagaimana tercantum dalam alinea 4 (empat) Pembukaan Undang-Undang Dasar 1945 dan Pasal 27 ayat (2) jo Pasal 28 D ayat (2) Undang-Undang Dasar 1945. Pembangunan di lakukan dari waktu kewaktu. ${ }^{60}$ demikian pula pembangunan Masyarakat Ekonomi ASEAN harus dilakukan dari waktu kewaktu.

Teori pembangunan ekonomi yang dikemukakan oleh Suryana, yang menyebutkan, pembangunan ekonomi, adalah proses multi dimensional yang melibatkan perubahan-perubahan besar dalam struktur sosial, sikap-sikap mental yang sudah terbiasa, dan lembaga nasional termasuk pula percepatan/akselerasi pertumbuhan ekonomi, pengurangan pemberantasan kemiskinan yang absolut. ${ }^{61}$

\section{PENUTUP.}

Masyarakat Ekonomi ASEAN diartikan sebagai sebuah masyarakat yang saling terintegrasi satu sama lain (maksudnya antara negara yang satu dengan negara yang lain dalam lingkup ASEAN) dimana adanya perdagangan bebas diantara negara-negara anggota ASEAN yang telah disepaki bersama antara pemimpin-pemimpin negara-negara ASEAN untuk mengubah ASEAN menjadi kawasan yang lebih stabil, makmur dan kompetitif dalam pembangunan ekonomi.

Masyarakat Ekonomi ASEAN (MEA) akan segera diluncurkan akhir tahun 2015 ini. Disadari atau tidak, MEA akan sangat terkait dengan kompetisi yang makin tajam di kawasan Asia Tenggara. Kendati idealnya MEA dirancang untuk memberikan manfaat bagi semua negara anggota ASEAN, sistem kompetisi di Masyarakat Ekonomi ASEAN (MEA) harus dicegah, dan tidak boleh dikembangkan di Indonesia, karena praktek kompetisi tersebut sangat

\footnotetext{
57 Ibid. hlm 198-199.

60 Rochmat Soemitro, Op. Cit. hlm. 14.

61 Suryana, Loc. Cit.
}

Vol. II No. 01 Edisi Januari-Juni 2016. 
bertentangan dengan sistem integralistik (persatuan) demokrasi ekonomi Pancasila, yang mengutamakan menyeimbangkan perbedaan-perbedaan kepentingan di Masyarakat Ekonomi ASEAN (MEA) dengan tujuan kesejahteraan (pemerataan) bagi seluruh Masyarakat Ekonomi ASEAN (MEA). Sistem Masyarakat Ekonomi ASEAN (MEA) harus merupakan sub sistem dari sistem integralistik (persatuan) demokrasi ekonomi Pancasila. 


\section{DAFTAR PUSTAKA}

\section{A. Buku.}

Arief Sidharta, Cita Hukum Pancasila, Makalah Kuliah Program Pasca Sarjana $\mathrm{DIH}$, tanpa penerbit, tempat, tahun.

Bagir Manan, Hubungan Antara Pusat dan Daerah Menurut UUD 1945, Sinar Harapan, Jakarta, 1994.

Bondan Gunawan, Apa Itu Demokrasi, Pustaka Sinar Harapan, Jakarta, 2000.

Darji Darmodiharjo, Sidharta, Pokok-Pokok Filsafat Hukum (Apa dan Bagaimana Filsafat Hukum Indonesia), PT Gramedia Pustaka Utama, Jakarta, 2008.

L.J. van Apeldoorn, Pengantar Ilmu Hukum, PT. Pradnya Paramita, Cetakan ke 21 (dua puluh satu), Jakarta, 1983.

Lili Rasjidi, Ira Thania Rasjidi, Pengantar Filsafat Hukum, Mandar Maju, Bandung, 2007.

Mariam Budiarjo, Dasar-Dasar Ilmu Politik, Gramedia Pustaka Utama, Cetakan XIII, Jakarta, 1991.

Mochtar Kusumaatmadja, B. Arief Sidharta, Pengantar Ilmu Hukum, PT. Alumni, Bandung, 2000. , Hukum Masyarakat dan Pembinaan Hukum Nasional, PT. Alumni, Bandung, 1976.

Konsep-Konsep Hukum Dalam Pembangunan, PT. Alumni, Bandung, 2006.

Moh. Mahfud MD, Politik Hukum di Indonesia, PT Raja Grafindo Persada, Jakarta, Tahun 2009.

Rochmat Sumitro, Pajak dan Pembangunan, PT. Alumni, Bandung, 1987.

Satjipto Rahardjo, Ilmu Hukum, Bandung, PT. Alumni, Bandung, 1982.

Sentosa Sembiring, Himpunan Undang-Undang Tentang Perlindungan Konsumen dan Peraturan Perundang-Undangan Yang Terkait, Nuansa Aulia, Bandung, 2007. 
SF. Marbun et al, Dimensi-Dimensi Pemikiran Hukum Administrasi Negara, UII Press, Yogyakarta.

Soerjono Soekanto, Faktor-Faktor Yang Mempengaruhi Penegakan Hukum, PT RajaGrafindo Persada, Jakarta, 2005.

Sri Haryani, Hubungan Industrial Di Indonesia, UPP AMP YKPN, Yogyakarta, 2002.

Sunaryati Hartono, Politik Hukum Menuju Sistem Hukum Nasional, PT. Alumni, Bandung, 1991.

\section{B. Peraturan Perundang-undangan.}

Undang-Undang Dasar Negara Republik Indonesia 1945.

\section{Jurnal, Artikel, Makalah, Majalah, Koran, Internet, dan Lain-lain.}

Bambang Rahardjo, Sumber :http://sukasosial.blogspot.com/2015/08/ masyarakat-ekonomi-asean.html.

Tim Pengajar PIH FH Unpar, Pengangtar Ilmu Hukum, Universitas Katolik Parahyangan, Bandung, 1995. 